\title{
LEGIBILITY OF INDUSTRIAL SITES: WAY-FINDING IN THE RUHR, THE EUROPEAN CAPITAL OF CULTURE 2010, AS A MODEL FOR INDUSTRIAL SITES IN ESKIŞEHIR, TURKEY
}

\author{
AYŞE DUYGU KAÇAR \\ Eskişehir Osmangazi University Department of Architecture, Turkey
}

\begin{abstract}
Industrial regions and buildings that have stopped their primary functions are in the interest of the discipline of architecture in the last decades. The sustainability and renewal of these spaces of production for different functions is a common aspect for contemporary world countries. This helps improve the social, cultural and aesthetic character of these buildings and sustains their uniqueness. The Ruhr region in Germany was selected as "the European Capital of Culture" in 2010, with the reprogramming of distinguished industrial monuments and their cultural landscapes. The industrial sites as the reference points became significant program elements for both domestic and foreign visitors for experiencing the region through these landmarks. The most memorable artistic reference points were the huge yellow balloons in the sky that indicate each industrial site. These balloons, which could be observed from long distances, directed visitors to the cultural sites during a temporary installation in June 2010. This creative work of art helped to identify the buildings as well as their sites, which were part of the IBA Emscher Park project. Eskişehir in Turkey could be another city that highlights its industrial culture when its urban artifacts, which shape the urban identity and reside in the collective memory, are considered. Therefore, these sites in the Ruhr that link the past and future will be discussed as a model for the industrial areas in Eskişehir to sustain their place in the collective memory of the city in the present paper. This will help increase the legibility of industrial sites in Eskişehir and similar cities in the world.
\end{abstract}

Keywords: sustainability, way-finding, legibility, industrial sites, Eskişehir, Ruhr.

\section{INTRODUCTION}

The built environment, as a medium of communication, exhibits both explicit and implicit symbols that tell us about ownership, relationship, class, concealed meanings, proper behavior, and more that can be functional or appealing to know in urban life. Kevin Lynch calls this component of sense legibility, "the degree to which the inhabitants of a settlement are able to communicate accurately to each other via its symbolic physical features" [1]. While asserting that legibility is crucial in an urban setting, Lynch [2] depicts an easily identifiable environment, a pattern of recognizable symbols. Instead of a mystic "instinct" of way-finding, he mentions sensory cues from the external environment, like color, light, smell, sound, touch, etc. To Lynch, the environmental image is strategic in way-finding and he describes it as "the product both of immediate sensation and of the memory of past experience, and it is used to interpret information and to guide action" [2, p. 4]. Similarly, according to Herzog and Leverich [3], legibility is a characteristic of the space and it helps understanding through cognitive maps and way-finding. Past experiences, along with the immediate sensation of the built environment, form the layers of the city. According to Bell and Dourish [4], the first of the various layers of the urban environment is the physical setting, with all buildings and topological relations. While the traces of history in the physical environment are the second layer, cultural experience, including the religious, individual or social, is the third. 
The conservation and renewal of post-industrial buildings and their sites in the Ruhr Region are considered for the sustainability of these layers, namely the explicit and implicit symbols in Germany. Because, as Lynch [2] underlines, "every citizen has had long associations with his city, and his image is soaked in memories and meanings" (p. 1). In 1980, the first monument protection law of NRW announced that all the objects and their parts in the public interest are monuments. These objects that were important in collective memory did not require aesthetic values [5]. Since all types of industrial production sites, including coal mines and coking plants, were a part of the country's identity, the preservation of industrial sites and buildings became a main concern in North Rhine-Westphalia, Germany. Sustaining the unique witnesses of the past experience and ways of living helped improve the social, cultural and aesthetic character of the environment. As "the European Capital of Culture" in 2010, the physical setting of the Ruhr region in Germany depicted the traces of history and the cultural experience. The reprogrammed public images and their cultural landscapes turned out to be reference points for inhabitants and newcomers. While experiencing the layers of the Ruhr through these landmarks, huge yellow balloons in the sky indicated each industrial landmark of the region. These landmarks became more easily identifiable with the balloons, which can be observed from great distances (Figs 1 and 2).

In fact, in 2009, Essen Affairs [6] announced that:

This year, yellow test balloons already sailed impressively above the Ruhr district. From far up in the sky, they pinpointed the mine shafts and tunnels far below, symbols of bygone eras of heavy industry - and a distinctive yet frequently overlooked feature of the region. As many assert with bemused pride, the Ruhr district is the only metropolis in the world with a full system of underground tunnels. In May 2010, 400 large yellow balloons will ascend over the mine pits. Shining brightly 40 metres above the earth, they will show how much the Ruhr region has change. (p. 17)

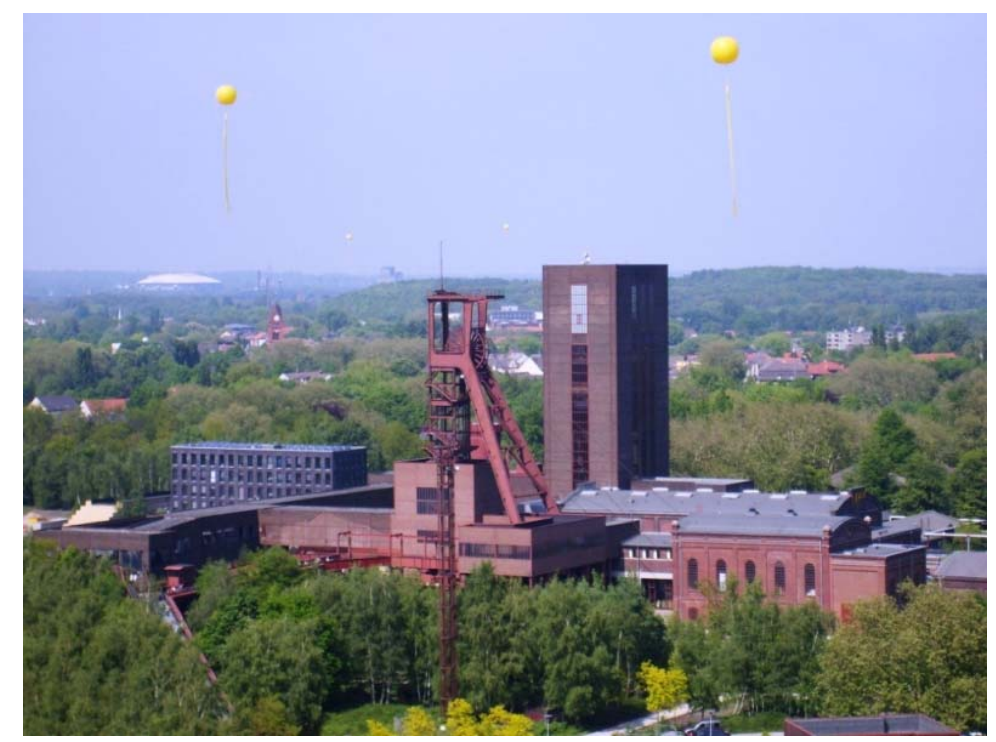

Figure 1: Both domestic and foreign visitors come to see these symbols of the industry. (Source: Photographed by the author.) 


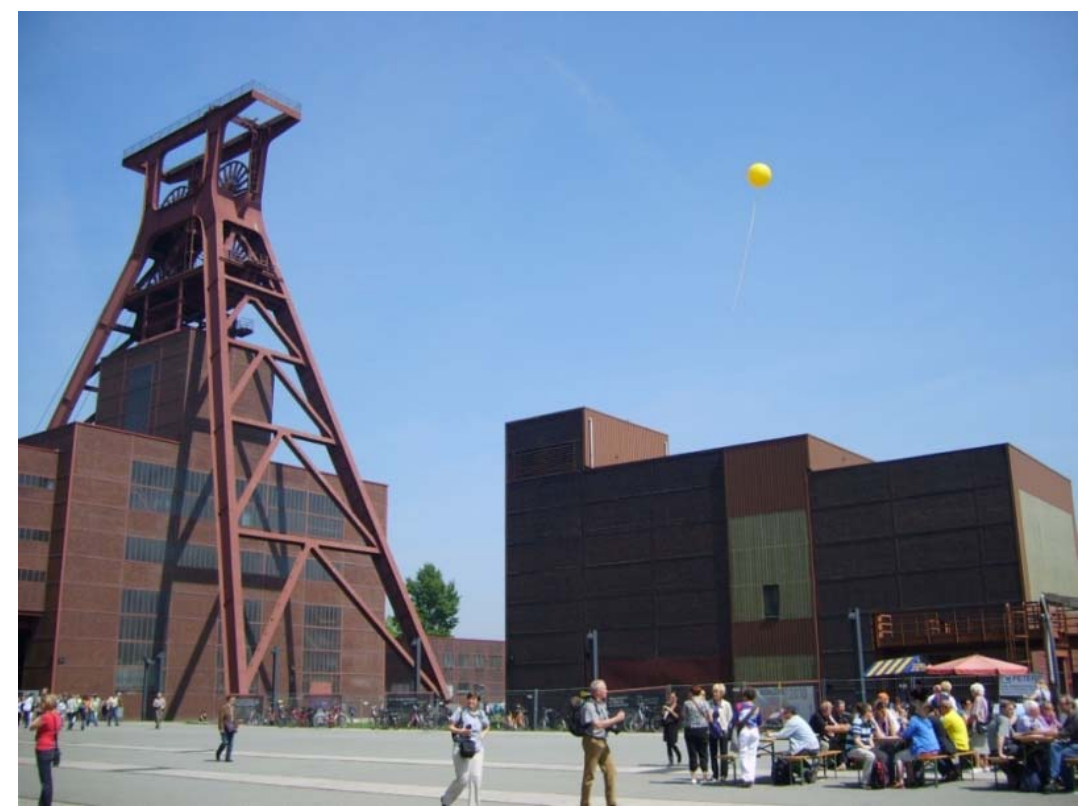

Figure 2: The renovation of the industrial sites developed these structures into architectural monuments and became the focus of attraction. (Source: Photographed by the author.)

Through a few changes, 311 large yellow helium balloons were taken to a height of up to 80 meters as "Shaft Signs" in May 2010. These signs were indicating that Ruhr, the postindustrial region, was transformed into a metropolis of the future with the renovation of the former coal mines and steel industry. Therefore, the largest art installation in the world was visible for nine days over an area of $4000 \mathrm{~km}^{2}$. Although the project was designed and directed by Volker Bandelow, more than 5000 actors participated in this social work of art and 2100 people helped to prepare it [7]. Furthermore, on May 24 and 29, the balloons were illuminated between $10 \mathrm{pm}$ and $1 \mathrm{am}$, which made the event more mystical. This also helped to identify the industrial sites in the evening for the events "ExtraSchicht: The Night of Industrial Culture".

\section{ESKIŞEHIR, UNESCO CAPITAL OF INTANGIBLE HERITAGE IN 2013}

The city of Eskişehir, which was nominated as a UNESCO Capital of Intangible Cultural Heritage in 2013, has been linking East and West for many centuries in Central Anatolia, but this modest town has become a more privileged location as a result of the connecting nature of the railway system. After the railway line reached the town in 1892, Anadolu Osmanl1 Kumpanyası (the Locomotive Maintenance Atelier) became the first industrial establishment in the city in 1894 [8] (Fig. 3). However, Eskişehir gained its industrial character with the encouraging policies of the new republic after World War I. The new government's emphasis on national production for economic self-sufficiency gave way not only to state enterprise, but also to private investments all around the country. The railway system provided an exceptional place for the cities on its network, and Eskişehir was located between the previous and recent capitals of Turkey. 


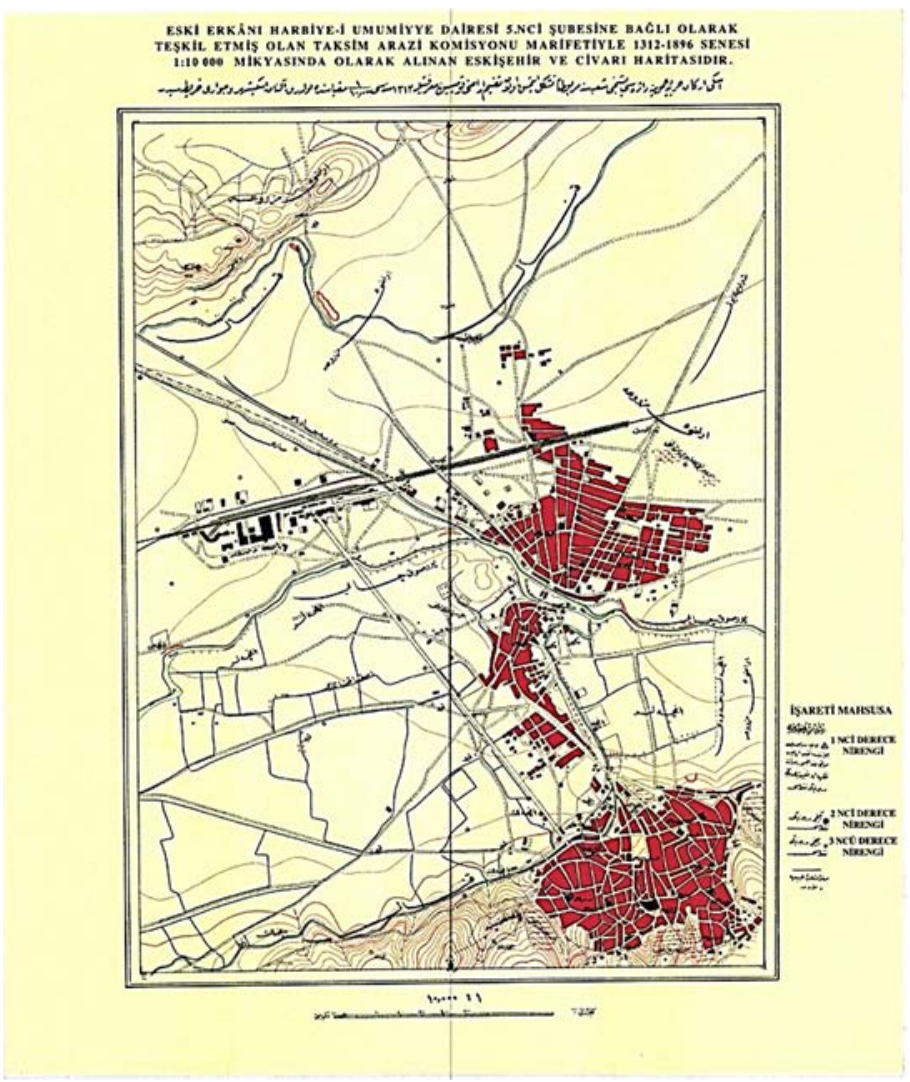

Figure 3: The black buildings on the railway line belong to the Anadolu Osmanl Kumpanyas1 (the Locomotive Maintenance Atelier) that was established in 1894, while the red ones indicate the city of Eskişehir. (Source: Eskişehir Metropolitan Municipality.)

In fact, the 448-km-long Porsuk River, which flows into the Sakarya River, defined the character of the city before the railway. The presence of the Porsuk River as the water source made agriculture possible, and the city of Eskişehir grew rich from vineyards, orchards and grain from the 15th century to the 1890s. In the first quarter of the 1900 s, mills were an important source of income, and the city became a cereal depot. The minorities that once lived in Eskişehir, such as the Greeks and Armenians, took part in economic life and played an important role in the city's physical formation. Although the city had a pre-industrial town character with its population of 15-20,000 before 1923, the emergence of various industries effected the development of the city by 1924 [9]. The İzmir İktisat Kongresi (İzmir Economic Congress) held in 1923, the subsequent Teşvik-i Sanayi Kanunu (the Law for Encouragement of Industry) and the new republic's five-year plans for an industrialized country contributed to changing Eskissehir's character into that of an industrial town.

After the establishment of the railway factory in 1924, an airplane maintenance center was founded in 1926, and both became the engines of national production in the Early Republican period. Along with these industries, sugar factories were another state enterprise for 
encouraging national production. This was one of the significant assurances of the nation's economic independence. The earliest sugar factories were established in Uşak, Istanbul and Alpullu by 1925. Years later, the Anatolian Sugar Factory was founded in Eskişehir in 1933 as part of the network that surrounded the country [10]. Sugar factories included model farms for distributing modern agricultural production tools and techniques as well as educating the new generation. These factories also produced machines for agriculture in addition to preparing crops for peasants. The sugar factory in Eskişehir was one of the three main machine factories and was established to set up new factories in Anatolia. Similarly, the Sümerbank Textile Factory was founded in Eskişehir as one of the Sümerbank factories that had been constructed all around Anatolia by 1933 as state enterprises. In fact, all of the state enterprise factories, as well as the small and medium-scale private ones, were located close to both the Porsuk River and the railway, related to their infrastructures. However, the Porsuk River has been one of the defining macro-form factors in the development of Eskişehir. Most of the industrial sites in Eskişehir lie along this river, which passes through city lands from west to east (Fig. 4). At the southwest of the city, Sümerbank is located right on the Porsuk River. While Tülomsaş and other small and medium-scale private factories, are located close to the railway station, the sugar factory is located in the east, between Porsuk and the railway. In the industrialization process, the factories and enterprises that were established on Porsuk caused its pollution. Specifically, the Sümerbank print cloth factory defined the color of the Porsuk River by the color of the textiles it produced. As a result, the part that runs through the city center was rehabilitated by the State Hydraulic Works (DSI), and the natural water course was transformed to a concrete reservoir in order to control the pollution as the population increased. After 1970, the law of common hold led to attached houses and imposed a barrier between the river and the inner parts of the city. For a long period of time, the presence of the river was not perceived as a positive artifact, and it tended to be forgotten. In the later urban renewal works, the presence of the Porsuk River became important for the city.

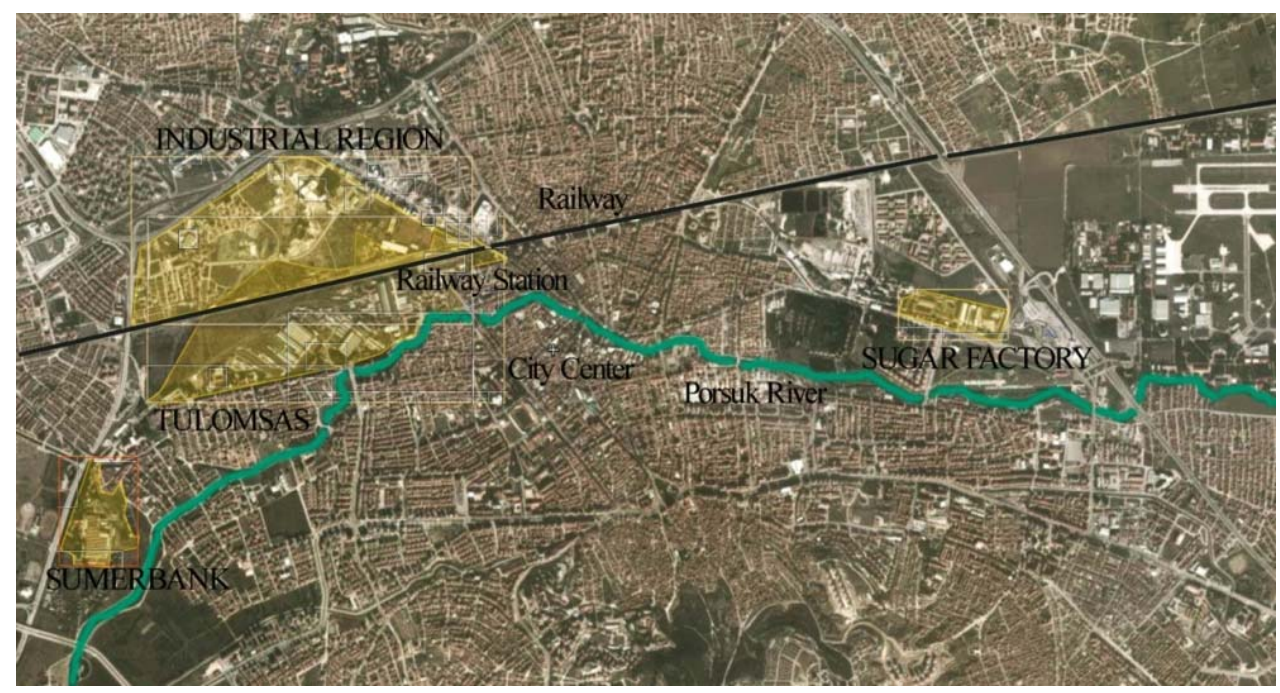

Figure 4: Mainly sugar factory settlements, the Locomotive Maintenance Atelier (Tülomsaş) and Sümerbank Textile Factory lie along this river on east-west direction. (Source: Google Earth.) 
All of the industrial sites and the buildings constructed since 1894 determined the evolving neighborhoods in Eskişehir. The tile, brick and food production sites on 62 hectares transformed the city's micro-form over time. Significantly, with the production of brick and tile from earth from the steppe, Eskişehir became one of the symbolic industrial cities in Turkey. Today, most of these industrial sites have distinguished campuses within the city center. Moreover, they are important places in the collective memory of not only the inhabitants but also the nation. Namely, in 1957, the engineers at the railway factory produced the first national small-scale steam locomotive. This gave way to arrangements for the first national steam locomotive, "Karakurt" (Blackwolf), in 1958. Soon after, in 1961, the first national car, "Devrim" (Revolution), was also designed and produced by Turkish engineers and architects at the Eskişehir Railway Factory (Fig. 5). These cars, only four in number, represented national success and willpower.

The small and medium-scale factories that were constructed mostly between 1928 and the 1950s in factory districts began to be closed down in the 1990s in accordance with the government's privatization policy as well as local authorities' environmental concerns; the Sümerbank textile factory (Figs 6 and 7) was transferred to the private sector in 1996.

There is speculation that both Tülomsaş and the sugar factory will share the same fate in the near future. However, today, most of the private industrial sites are being demolished for their rent of land. New residences, office buildings and shopping centers are emerging on the sites of these cultural landscapes. Namely, the Mühendisler Flour Factory, which was established in 1953, was burned down to build the Özdilek Shopping Mall, even though it was a registered building. Another demolished example is the Kurt Tile Factory and, again, the site was used to construct a new shopping mall (EsPark) after it was destroyed in 1997.

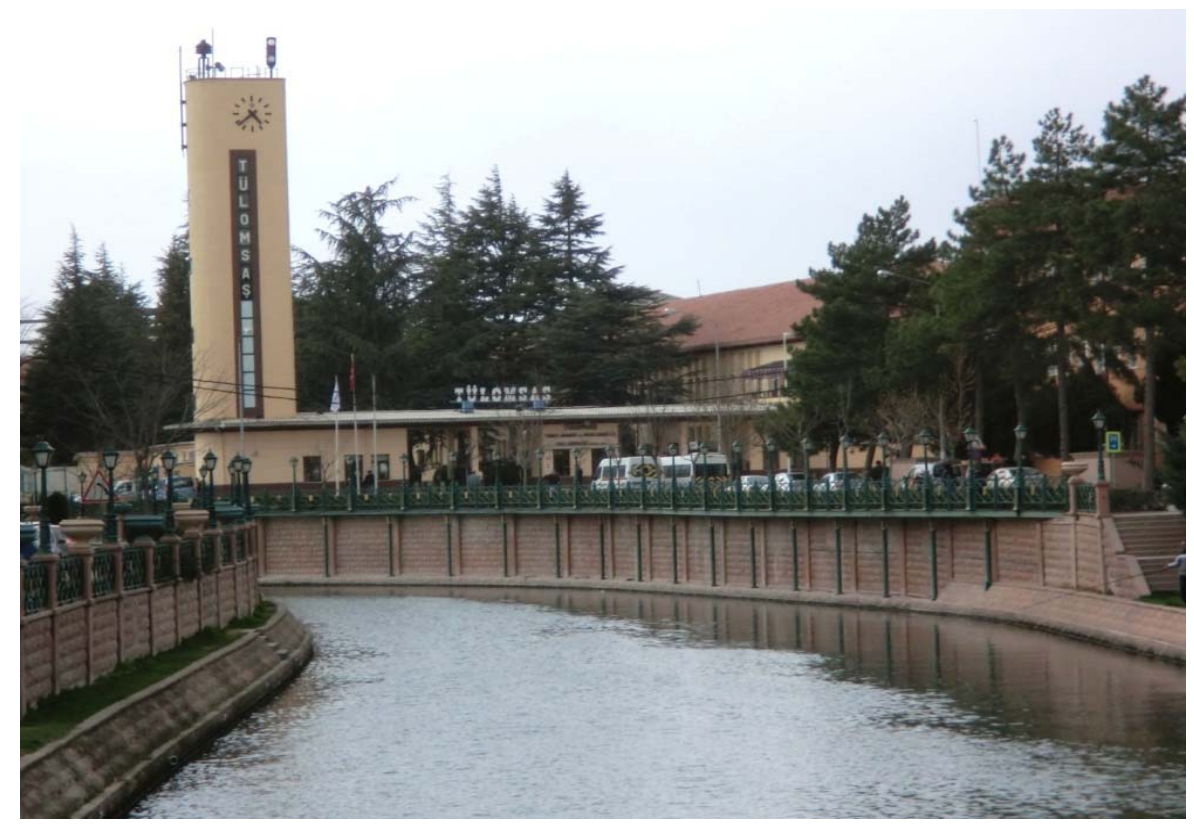

Figure 5: Tülomsaş, Eskişehir Railway Factory lies in between the Porsuk River and the railway at the city center. (Source: Photographed by the author.) 


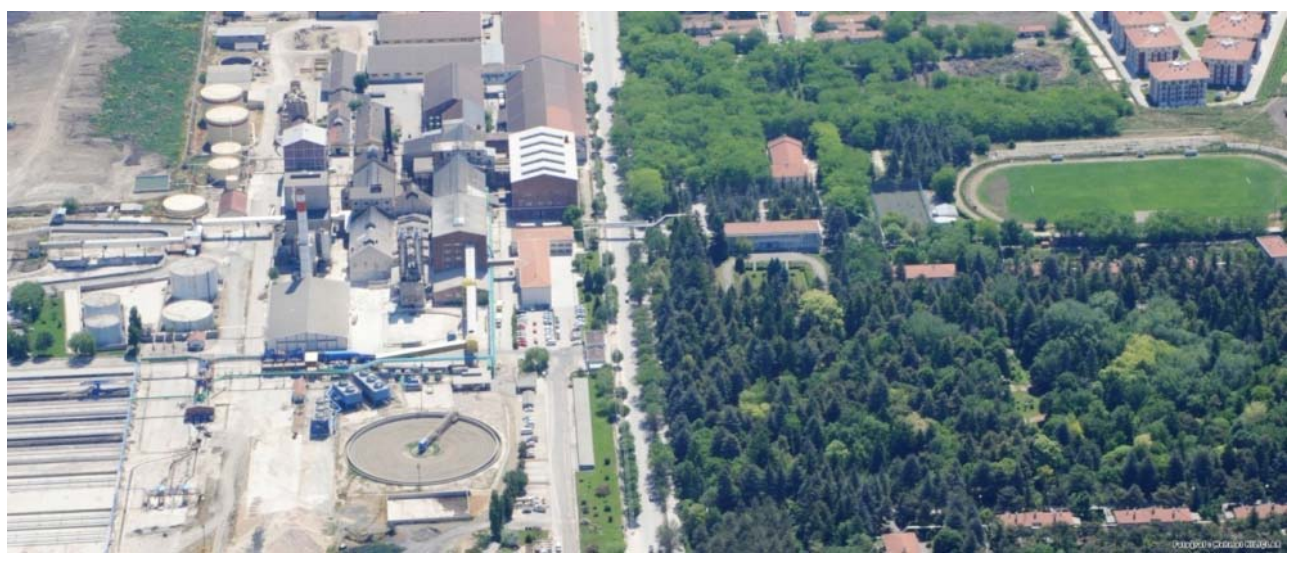

Figure 6: Sugar Factory buildings across the dwellings and social spaces for the workers in green surroundings [11].

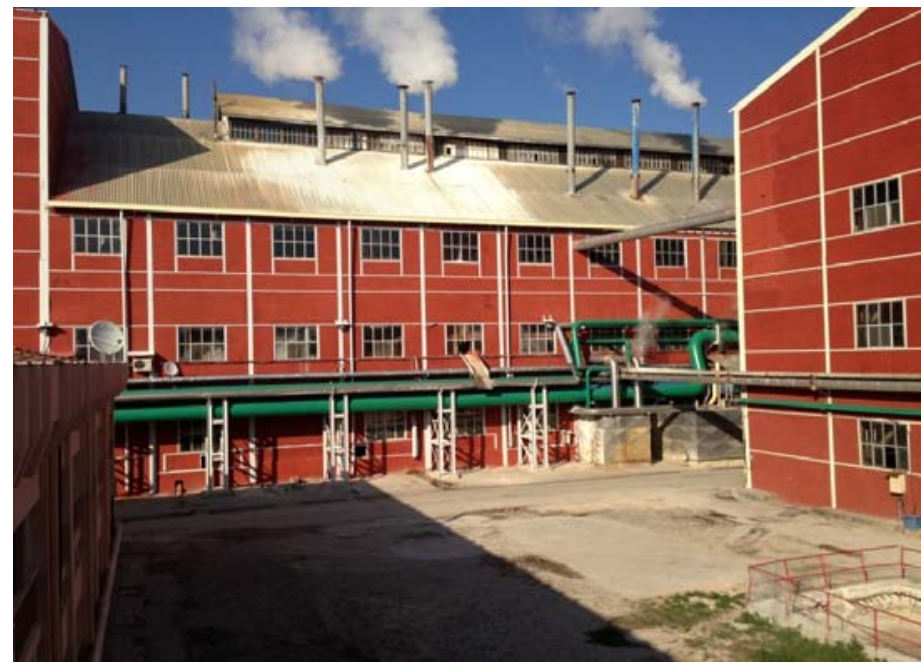

Figure 7: Sugar Factory buildings constructed with steel and local brick. (Source: Photographed by the author.)

In the case of EsPark, symbolic chimneys were reconstructed as a reminder of the site's previous use (Fig. 8). The surviving industrial buildings, such as the Aral Wine Factory and the Öç Tire Rim, were transformed into nightclubs (Hayal Kahvesi and Buda, respectively), but their interventions were discussed because of their limited use. More recently, the Kılıçoğlu Cinema in the city center, which had served as a social and cultural space for both the Kılıçoğlu tile and brick factory workers and the city's inhabitants, was first burned and then torn down in 2014 in order to construct a new shopping mall. Consequently, it can be noted that the industrial culture of the city is not taken into consideration in the city's prospects. 


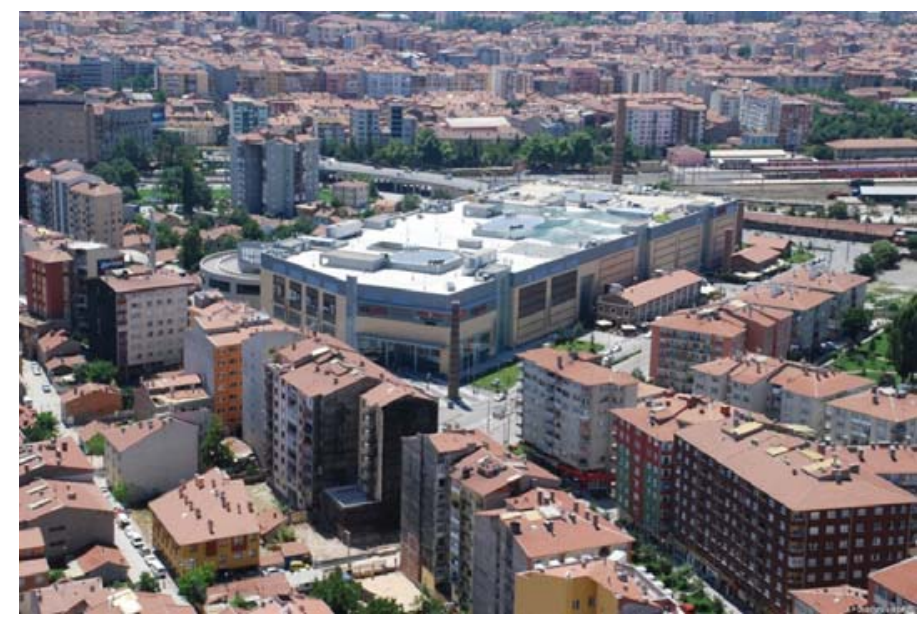

Figure 8: Symbolic chimneys were reconstructed to remind the former use of the site in EsPark case. This shopping mall is surrounded by former industrial buildings at the north, which are mostly used as cafes [12].

\section{CONCLUSION}

Industrial sites as the traces of history and cultural experiences are significant for the sustainability of explicit and implicit symbols. For being a witness of production and the ways of living of a specific period, the Ruhr region is an important part of the collective memory of Germany. The creative work of art in 2010 (as temporary elements) helped to identify the industrial buildings and their sites in the region. But, the high-winding towers that can be seen from long distances are permanent parts of the coal mines and help the legibility of these sites. However, the industrial sites in Eskişehir, which is a modest town in central Anatolia, are losing their legibility in the city. In her research, Öztürk [13] focuses on the effects of urban transformation in Eskişehir by using cognitive mapping. The research shows that the rapid transformation of urban space cleared the traces of history of the city as well as the cultural experiences from the collective memory of the inhabitants that were born before 1960 [13]. The few examples of how industrial culture was transformed into new living spaces, such as nightclubs, cafes and hotels in the city center, should be evaluated as a whole with other formerly industrial sites in a physical, social and economic sense to signify the identity of a period and its production techniques. Therefore, the legibility of industrial sites is important in the sense of making the city's image more clear and remarkable to the city dweller, since the environmental image as the picture of the physical world is strategic in way-finding. Because, both the past experience in memory and the instant sensation shape the image of the physical environment and guiding actions.

\section{REFERENCES}

[1] Lynch, K., Good City Form, MIT Press: Cambridge, MA and London, p. 139, 1981.

[2] Lynch, K., The Image of the City, MIT Press: Cambridge, MA and London, pp. 3-4, 1960.

[3] Herzog, T.R. \& Leverich, O.L., Searching for legibility. Environment and Behavior, 35(4), pp. 459-477, 2003.

[4] Bell, G. \& Dourish, P., Getting out of the city: Meaning and structure in everyday encounters with space. Ubiquitous Computing Workshop on the Urban Frontier at 
Ubicomp, Nottingham, UK, 2004. Online. http://www.dourish.com/publications/ 2004/urban.pdf. Accessed on: 13 Jan. 2017.

[5] Durchholz, U. \& Pfeiffer, M. On the way to the future: Zollverein after the closure. Welterbe Zollverein World Heritage Site, Stiftung Zollverein (Hrsg.), Klartext: Essen, pp. 109-178, 2008.

[6] https://www.messe-essen.de/media/neue-medien/dreiklang/magazin-essen-affairs/ 2009 2_essen_affairs_eng.pdf. Accessed on: 13 Jan. 2017.

[7] http://www.marketwired.com/press-release/311-giant-balloons-launched-overeuropean-capital-culture-ruhr2010-shaft-signs-the-largest-1264929.htm. Accessed on: 13 Jan. 2017.

[8] http://www.tulomsas.com.tr/main.php?kid=67. Accessed on: 13 Jan. 2017.

[9] Aksoylu, S. Cumhuriyet Dönemi'nde Sanayi Tesislerinin Eskişehir'in Mekansal Gelişimine Etkileri. Eski Yeni: Aylık Şehir Kültürü Dergisi, Eskişehir Valiliği: Eskişehir, 46, pp. 48-55, 2012.

[10] http://www.turkseker.gov.tr/Tarihce.aspx. Accessed on: 13 Jan. 2017.

[11] http://www.eskisehirliyiz.biz/galeri/resim.asp?fotoid=5891. Accessed on: 13 Jan. 2017.

[12] http://www.eskisehir.net.tr/galeri/resim.asp?fotoid=5778. Accessed on: 13 Jan. 2017.

[13] Öztürk, A., Eskişehir'in Geçmişteki ve Bugünkü Kent Belleğinin Zihin Haritaları Üzerinden Okuma Denemeleri [A reading attempt of the past and present urban memory of Eskisehir via cognitive mapping]. Ideal Kent [Journal of Urban Studies], 20(Special Issue on Memory and Urban Conservation II), Ankara, 2016. 